Матеріали Всеукраїнської науково-практичної конференції «Актуальні питання діагностики, лікування, раціональної фармакотерапії, диспансеризації та реабілітації в практичі сімейного лікаря"

DOI

\title{
ЕФЕКТИВНІСТЬ РІЗНИХ СХЕМ ДЕНС-ТЕРАПІЇ У РЕАБІЛІТАЦІЇ ХВОРИХ НА ХРОНІЧНИЙ ПАНКРЕАТИТ
}

\author{
слЛ. С. Бабінець, Ю. Я. Коцаба
}

ДВНз «Тернопільський державний медичний університет імені І. Я. Горбачевського мОз України»

Мета роботи - порівняти ефективність впливу двох різних схем застосування динамічної електронейростимуляції (ДЕНС-терапії) на рівень якості життя у хворих на хронічний панкреатит (ХП).

Методи дослідження. Оцінку досліджуваних параметрів проводили за допомогою загального опитувальника SF-36 і спеціалізованого опитувальника гастроентерологічних хворих GSRS.

45 обстежених хворих на ХП у фазі стійкої чи нестійкої ремісії поділили на дві групи: 1 (25 чол.) отримувала загальноприйняту терапію ХП «за вимогою» + курс ДЕНС-терапії (12 - 14 сеансів, лабільним методом у режимі «Терапія» в комфортному енергетичному діапазоні впливу (ЕД) - 2 по 5 хв на ділянку). Діяли на сегментарні зони: прямої проекції больових відчуттів (індивідуально у кожного хворого) та прямої проекції підшлункової залози (епігастральна ділянка) на частоті 77 Гц; сегментарного кільця на рівні 6-8 грудних сегментів на частоті 60 Гц 3-5 разів, замикаючи коло; попереково-крижова зона на частоті 20 Гц. 2 група (20 чол.) отримувала аналогічне медикаментозне лікування + курс ДЕНС-терапії, але за іншою схемою: виносним точковим терапевтичним електродом, стабільним методом в режимі «Терапія» на частоті 60 Гц при ЕД - 2 по 2-3 хв на точку. Обробляли наступні точки: АТ 96 - проекція підшлункової залози; АТ 55 - точка шень-мень (знеболюючий та седативний ефект); АТ 22 - точка залоз внутрішньої секреції; АТ 39 - точка грудного відділу хребта (знеболюючий та протизапальний ефекти). Точки проекції підшлункової залози на долоні та стопі за системою Су Джок.

Результати. Вихідні дані хворих на ХП в обох досліджуваних групах були зіставними. Після проведеного курсу лікування за запропонованими схемами отримані дані виявилися достовірними $(p<0,05)$ відносно таких до лікування. Порівнюючи результати обох груп встановили достовірне $(p<0,05)$ переважання значень рівня якості життя серед хворих на ХП у 2 групі. Так, за шкалами опитувальника GSRS абдомінальний біль зменшився на 28,57 \%, гастральний рефлюкс - на $18,48 \%$, діарея - на 23,14 \%, диспепсичний синдром - на 13,58 \%, констипаційний синдром - на 2,14 \%. Показники опитувальника SF-36 відповідно зросли: фізичне функціонування на $47,56 \%$, рольове функціонування - на $40,03 \%$, загальний стан здоров'я - на 28,48\%, життєва активність на 7,10\%, соціальне функціонування - на 3,63\%, емоційне функціонування - на 18,3 2\%, психічне здоров'я - на 5,23 \%. Слід зазначити, що дані за шкалами констипаційного синдрому та соціального функціонування виявилися недостовірними $(p>0,05)$.

Висновки. Застосування ДЕНС-терапії у хворих на хронічний панкреатит за обома запропонованими схемами достовірно покращує рівень якості життя хворих на хронічний панкреатит. Але доведено, що її вплив на точки акупунктури має достовірну перевагу над сегментарною схемою. 